\title{
COMMUNICATIVE CREATIVITY: FROM CUSTOMARY METAPHYSICS TO ORIGINAL ONTOLOGY
}

\author{
Nerijus STASIULIS* \\ Vilnius Gediminas Technical University, Faculty of Creative Industries, Department of \\ Philosophy and Cultural Studies, Traku str. 1, Vilnius 00132, Lithuania
}

Received 3 July 2018; accepted 14 November 2018

\begin{abstract}
This paper deals with the metaphysical basis of creative communication in the society and the creative city and seeks to uncover the metaphysical grounds of the practical issues we currently face in our everyday academic life and economy. The focus is on the metaphysics of genius and also on former Christian metaphysics of creation from nothing and the importance of individual will as the predecessors of genius. Both Western rationalism as manifested in definite boundaries of sciences and the irrationalism as manifested in metaphysics of genius still shape the framework of our current thought and polemics relating to copyright and patent law, the communication (collaboration) of sciences and arts. After rooting the practical problematic in its metaphysical context, this paper provides a Heideggerian reworking of Western metaphysics to shape an original ontology which is to shape practice in time to come. The notion of ecstatic time itself proves to be of key importance to original creativity.
\end{abstract}

Keywords: copyright, creativity, genius, Heidegger, interdisciplinary communication, ontology, patent law.

\section{Introduction}

Modern (and postmodern) time is defined by the notion of the creative subjectum which, nevertheless, has its roots in antiquity. Its subjectivity, which manifests in a creative-technological manner, differs from the Heideggerian Dasein in that the latter, as a site for Being's revelation, can be described as an ecstatically passive activity whereas the former has nothing to do with this passivity and is in this sense self-sufficient and absolutely active. Manifesting this activity is what postmodern creativity consists in.

The notion of creativity may derive from the ancient Roman "creatio" which later, in Christianity, acquired the meaning of creation ex nihilo and, then, at the dawn of modernity, turned into the poetic creation de novo. In the 19th century it was considered merely a concept of aesthetics, while in the 20th century the concept expanded to include scientists and

${ }^{\star}$ Corresponding author. E-mail: nerijus.stasiulis@vgtu.lt 
engineers and, eventually, all artistic and scientific (or scholarly) activity, which can now be organized and stimulated by providing a suitable social environment (cf. Kačerauskas, 2014, p. 8). In medieval times creation was divine but in modern and postmodern times we can notice, instead, a divinization of society and individuals whose happiness can be easily attained by technological and communicational means.

Some authors (cf. Kačerauskas, 2014, p. 8) make a distinction between the meanings of the Latin "creatio" and "facere" because they deem the latter an equivalent of the Greek "poiēsis". Facere/poiēsis is, thus, considered to denote a notion of defined boundaries, while creatio denotes the possibility of novelty. In this paper, we shall try to befriend these two notions by drawing on Martin Heidegger's work on Western ontology. His work is relevant because in it both the notion of the creation from nothing and the Greek notion of poiesis have merged. Thus we shall be able to discover a "common denominator" for creatio and poiessis and to see the history of Western ontology from its beginning in ancient Greece till today as a unified manifestation of a single principle. This shall allow us to construe creativity as an ontological issue and to capture the basic meaning which unifies different fields of its manifestation.

The creative society also faces a couple of practical issues. First of them is the growing need for interdisciplinary communication and cooperation for the sake of the development of creative solutions but it is hindered by the traditional definite boundaries of sciences. We can recognize in this conflict the image of the aforementioned dualism between facere (as indicating closed boundaries) and creatio (as indicating open novelties). Another issue has to do with the legal protection of creation and creators as a social group which might be seen to hinder communication. They are provided with the copyright and the patent law but these rights, in turn, originate conflicts in society which hinder the development of the economy based on creativity. As the boundary between discovery and invention fades, creative workers invade different fields of life and try to "privatize" social (including, natural) property based on their patent law. The conflict arises precisely in the attempt to distribute and redistribute this social property because the winners are plainly those who are the first to reach the patent office (Kačerauskas, 2012, p. 75). Furthermore, patenting new ideas can become a serious bureaucratic hindrance to creativity. However, these practical issues shall concern us only inasmuch as they manifest an ontology as opposed to attempting practical solutions.

In this paper we shall not delve into practical issues but only use them as an occasion to delve into deeper metaphysical or ontological level upon which the practical problematic of technology and communication in fact rests. We shall take up the approach which is more important than practical solutions; we shall be after a change of aspect (Ludwig Wittgenstein) that shall allow us to take up a more original stance in the face of both practical and theoretical challenges. ${ }^{1}$

\footnotetext{
${ }^{1}$ Lately, some articles have discussed communication theory from a Heideggerian or philosophical perspective: Youngjoon Choi and John Dattilo (2017), Edvardas Rimkus (2018), Jessica N. Sturgess (2016), Shirley Ou Yang (2016) and Ștefan Vlăduțescu (2014).
} 


\section{From practical issues to ontological solutions}

The legal principles of copyright and patent law, which define communication in the economic-technological field, have metaphysical roots. They are the offspring and an expression of the metaphysics of genius wherein our notion of creativity is embedded. Genius is an individual who can create from nothing (ex nihilo). That means he is ascribed the power which, previously, had been available to (Christian) God and only to Him. One could even link the birth of genius to the death of God whereupon genius inherited the power to create ex nihilo. Now that artistic (and, eventually, any) creation was self-made, the creator was destined to claim the ownership of his creation. Consequently, he was entitled to copyright and patent law, that is he was acknowledged the exclusive right to manipulate the fruit of his creative endeavor for the sake of his own gain, sustenance and growth.

The individualism in the notion or consciousness of genius sprang also (alongside the notion of creation from nothing), obviously, from Christian metaphysics. The notion of the creation of the world and the soul from nothing brought about the consciousness of the soul's constant hanging above the abyss of nothingness where into one could at any time be brought back if it was not for the sustaining power of God (Athanasius of Alexandria). A Christian, as long as his nature remained sinful and ever in need of God's mercy, was at any moment in danger of eternal death. Hence the gratitude to God as his savior. Also, the direct experience of nothingness had the most individualizing effect. Ancient notions of eternal recurrence of the same provided a basic sense of unity (or publicity) of all things with eternity, or the one, the eternal living principle, while the Christian experience of the ex nihilo called for monastic meditation and discipline. Will had to be discovered and employed for the sake of saving one's metaphysically mortal soul, and the discovery of will opened the possibility of novelty.

We cannot overemphasize the importance of the introduction of the new linear time (Augustine of Hippo) as opposed to circularities of the ancient world. Modernity was shaped largely by the victory of will's creativity against the regularities of the intellect as well as by the victory of linear time against circular (hence, eternal) time. Our assertion could be opposed by noting the crucial importance of mathematical rationality for modernity. But, to reply, mathematical science soon revealed its technological nature, that is, its subjection to will's creativity (also see Stasiulis, 2016a). The eternity of the world, or the eternal forms, or the God-written mathematical laws, were expropriated by the human mind and put to service of the human kind. Analogically, the modern rational political order was expropriated by individualized national states for their own sakes. Also, rationalization of life was expropriated for the sake of individual human rights (especially, the right to life and the pursuit of happiness). Making of the world and of things was expropriated by genius. Later, the notion of genius spread out from being ascribed to single individuals of exceptional excellence to being the essential property of any creative endeavor and to belonging to many, if not any, individuals or the systems in which they are contained (cf. Černevičiüte \& Strazdas, 2014). If every Christian had an (im)mortal soul, every postmodern has creativity. The exercise of creativity can be seen as an analog of and a substitute for Grace.

However, every solution entails its own problems. First of all, if creativity is conceived as an essentially immanent force, how about the basic human need for transcendence (noted 
by Immanuel Kant, Wittgenstein and Emmanuel Levinas, among many others)? If creativity is employed in the pursuit of happiness, can happiness be achieved autonomously, apart from transcendence? Secondly, if creativity is enjoyed by individuals, can it not be hindered by overly agonistic relations among individuals who do not share any kind of unity? How to overcome the tendency towards solipsism to make communication and cooperation possible? Does creativity take place in a common world? Can de-divinized world be enjoyed, even if we approach it ecologically (Parastoo Saeidi et al., 2018; Stasiulis, 2018a, 2018b)? Where shall we look for ontology that can sustain the new economic order of the creative society over and above the competition of copyright and patent owners? Thirdly and most importantly, how should the openness of creativity deal with the opposing tendencies towards stability and rigid determination?

In our view, these issues can be addressed in terms of Heideggerian musings on the (modern) subject and the Dasein. Firstly, Dasein's reciprocal relation with Being avoids the closure of immanence by dint of the clearing (Lichtung). Secondly, Dasein as being-with and as being in the fourfold avoids the overly agonistic and exploitative stance (and is, obviously, essentially communicative). Thirdly, Dasein is a novel construal of the fundamental Western notion of ousia and, accordingly, a transformation of ratio and logos ("language, discourse") in terms of the clearing wherein the opposition between the creative and the rigid dissolves. In brief, Dasein is a fundamental re-orientation of the subject which is but another name, or the ontological source, of the modern genius. Hence, the following musings shall be devoted to describing the relation of subject to Dasein.

\section{Creativity and presence}

Heidegger derives Greek thought - and, consequently, all Western thought - from the primary experience of presence. While presence (ousia) has been interpreted as "concept" or as "eternity", or as a "whole", Heidegger identifies it with a pre-conceptual source of isness and of creativity and he construes it as Being in essential relation to temporality. We must see it as a crucial re-reading of Greek thought - as opposed to plainly rejecting it - in a way that dissolves the fruitless opposition between strictly determined conceptual thought and interpretative interdisciplinary thought and reveals the condition of the possibility of communication and even cooperation among different conceptual spheres. We claim that Heidegger's reading let us understand better how different themes of thought in ancient thinking, based on the intuition of communicative unity of the common world, (first of all, Plato's and Aristotle's) could be subdued to clear definitions yet be utterly contextual and merging into one another. We could use it as a model for our own endeavor to think. For that purpose, we must learn more about the "other" thinking of Being (as of a pre-theoretical source of all theory).

To capture this pre-conceptual, or pre-theoretical, level of thought, Heidegger, in Being and Time (2006, in German: Sein und Zeit, originally published in 1927), introduces the "existentials" (Existenzialien) which are opposed to "categories". "Categorial" thinking - the source of both successes and failures of our communication - is our post-Aristotelian mode of revealing Being while "existential" thinking is recovered by novel phenomenological and hermeneutic re-reading of Aristotelian philosophy in its Greek context. The precursor to "existentials" 
(as a "window" to novel communication) in early Heidegger was "formal indication" (formale Anzeige) which was to touch the precognitive level and to approach "something" which borders on ineffability. The reason why Heidegger (2006, p. 3) emphasizes that Being is not the most general and the most empty of concepts is that it is not conceptual at all, i.e., just like in Husserlian formal indication, it cannot be grasped by the structure of genera and species.

In fact, Heidegger finds a pre-cursor to formally-indicative and existential thinking/ speaking in Aristotle - to wit, in his understanding of the analogy of Being. Ana-logia in Aristotle is "something" into which all namings or "katēgoriai" are said back or carried back to (ana-legontai or ana-ferontai). Heidegger points out that thus they all address or are linked to "one" Being which cannot be captured conceptually (1990, p. 43, 47). Also, importantly, Heidegger makes the distinction between "one" as "single" and "one" as "simple": simple is one but also manifold (2005, p. 153). Being is one as simple and is, hence, expressed manifoldwise. This meaning of "oneness" as "simplicity" is also Aristotelian (cf. Aristotle, 1984, 187a 1-3) and, according to Heidegger, this Aristotelian emphasis on manifoldness is by no means a rejection of Parmenidean thought but precisely an expression of it (1990, p. 27).

Here we have moved in the direction of the "structure" of ontological difference but, to note, in Heidegger the (re-)reading of Greek thought is always mediated by the Christian experience of transcendence. Thus, Theodore Kisiel also (1993, p. 20) traces the root of formal indication to the Scholastic version of the doctrine of analogy, first provided by Duns Scotus. On the other hand, it is a phenomenological reading based also on Heidegger's neo-Kantian predecessors. Heideggerian formal indication was born from the meeting of a medieval transcendental of unum and the "reflexive category" of the neo-Kantian Emil Lask (Kisiel, 1993, p. 26). "Constitutive" categories, for Lask, articulated reality while the "reflexive category" addressed "something" prior to logical dressing and objectification. This meant it was much like medieval transcendentals (ens, unum, verum, bonum) which played precisely the unifying role. When our ponderings moved towards the most general and the most unified, we were in the "area" of the "reflexive category". It indicated an unreflecting acceptance of the given.

To avoid making this givenness banal and "most empty" and "most general", we should note that this es gibt is meant to capture the very first movements of thought and its arising from the amorphous (perhaps, apophatic) homogenous experience of the thing-in-itself. In the Middle Ages, this primary Undifferentiated "something" was the ens commune. If we do not fail to think this Undifferentiated correctly, we realize that any generality here loses all sense as the Undifferentiated is obviously beyond the field structured by genera and species.

While this Undifferentiated is, in neo-Kantian terms, a homogeneous continuum, thinking arises at the border between the ineffable and the effable, between the Undifferentiated and differentiation. At this point of differentiation - in fact, reminiscent of Plato's (1993) ponderings in the Sophist - the couple of identity and difference, of "the one" and "the other" emerges; something can exist only by being different from another, by being not-other. The important thing, indicated formally, for Heidegger is that the alleged tautology of es gibt, ens est is in fact a heterology. Hence, Being manifests to thought as relation and as related where all "members" of the articulated sphere arise equiprimordially (gleichursprünglich). It is precisely in the context of describing the line between the undifferentiated and the differentiated that Heidegger first used the latter key term of equiprimordiality (Kisiel, 1993, p. 
37) which he later used to describe the mit-Sein and mit-Dasein of beings in the articulated (manifested, unconcealed) sphere of Dasein.

This "idea" of equiprimordiality of oneness and manifoldness and of identity and difference stretched from the early to the late period of Heidegger's philosophy. In the late work on the principle of identity (Heidegeris, 1992) the thinker claimed that the word(s) "the same" (der Selbe, to auto), just like the esti (es gibt) of Parmenides, presuppose a difference inside sameness. Whereas even for young Heidegger, pure monism without contraries could not even be thought, and therefore things (beings) existed, essentially, in Bewandtnis, in a nexus (cf. Kisiel, 1993, p. 37).

And the nexus-character of beings (which is precisely what enables communicating) as manifestation of the Undifferentiated is what the famous temporality of Being consists in. Heidegger claimed to have found this "insight" of Being's temporality in the Greek thinking of ousia. While in the course of history the temporal dimension had been overshadowed by the stability aspect of ousia, Heideggerian primordial interpretation sought to retrieve this crucial insight.

According to Heidegger, ousia, for the Greeks, meant constant presence (ständige Anwesung). While the stability, or constanty, aspect would consequently inform the basis of our conceptual and scientific endeavor, Heidegger, already in his early period, moved toward retrieving its temporal dimensions by noting that the transcentendal unum is related to intentionality and movedness (Bewegtheit). As Heidegger kept distancing himself from the conceptual worldless phenomenology of Edmund Husserl and the still object-oriented reflexivity of Lask, he came to consider intentionality as derived from the primordial stream of life which was self-sufficient or self-sustaining (here also note an influence of Meister Eckhart). Formally indicated phenomena were maximally general, indifferent and contentless so as to let appear the spontaneous understanding characteristics of lifestream itself. At this point phenomenology and hermeneutics coincided to give birth to peculiarly Heideggerian pondering. The step from objectifying phenomenology to "pre-phenomenological" hermeneutics of the stream of life and from the stilling conceptual grasp to formal indication which succeeded in not inhibiting this stream both presupposed the Heideggerian reading of Aristotle and was presupposed by it. This reading consists in 1) the destruction of our ontology derived from Greek thought and 2) a retrieval of the original meaning of the Greek Dasein from Aristotle's - and, consequently, prior Greek - thought. Thus, the desubstantialization of Dasein ("subject") in Being and Time went hand in hand with a revelation of the primordial temporal and communicative structure of Dasein, or ousia, based on a fresh taking-up of Aristotelian notions such as, most importantly, that of the structure of the kinessis of fysis, energeia and the relation of poiessis and pathēsis in movement. The relation of poièsis and pathessis in fact defines the "structure" of ontological difference (which is but another name for Being's temporal revelation).

\section{The creative and the definite}

Heideggerian notion of the ontological difference, of the difference between beings and Being, was made possible by the Christian notion of creation from nothing and of the radical difference between transcendent God and the created world. Here, of course, the crucial 
aspect is phenomenological - the experience of nihil as it was already explicated by Thomas Aquinas (see Aleksandravičius, 2009, p. 209). As we in part noted before, it is also the experience of gratitude, jubilation and worship. To put it differently, it is the experience of activity rooted in passivity. This is precisely what characterizes the Dasein and differentiates it from the subject as the basis for solipsism which hinders communication and cooperation.

Heed that we, in our Aristotelian-Heideggerian ponderings, do not have to be enclosed within the narrow confines of what the modern subject terms "rational" and, by re-reading the Greeks with the presupposition of ontological difference, we can attain a richer meaning of logos as of that which "gathers" (sammelt).

Aristotle - so important to Heidegger - himself was not as standardized a logician as its present-day decendants. While it was only in the 20th century that we started to realize that everyday live speech is not "logical" and has its own (unarticulated) rules, this knowledge was already present in Aristotle's texts. It existed precisely in the afore-mentioned notion of analogia. While logic operates with genera and species, Being itself cannot be caught in logic because Being's prior intentionality is the condition of the very possibility of logic.

Traditionally, the essence, or ousia, of a thing is caught in a ("logical") definition (orismos). As Heidegger now deals with pre-conceptual sources of "concepts", he is able to show the origin of ousiology itself from the Greek Dasein's revelation of the wordliness of the world. Aristotle is claimed by Heidegger to have taken up meanings from the everyday Greek language and brought them into his concepts (orismos, kateggoria, etc.) As if he remembered, or unconcealed, (brought to concept) what was there for every Greek in his or her casual communication to conceive or experience. Thus, Heideggerian discussion of ousia does not merely deal with the way this word is used in Plato's or Aristotle's texts; and Heidegger is not satisfied with mere statement that, for Aristotle, ousia is the first of categories.

In the Heideggerian phenomenologico-hermeneutic recovery, ousia reveals the field of Dasein itself and is shown to have two basic possibilities of meaning. First, the field can be appropriated by the gaze of the subject. Second, the field can be characterized by the reciprocal dependence of Being and Dasein. This interdependence is characterized by the activity of Dasein rooted in passivity, whereas in the first instance Dasein has turned into "mere" subject which is therefore absolutely active, devoid of any passivity.

The two possibilities were already there in the primordial intending (revealing) of ousia as the word itself, like its Heideggerian German "counterpart" Anwesen, means "property, having, stock" and the like. Now, upokeimenon, or - in Latin - subject(um), is the (phenomenal) field "had" by Dasein, the very origin of this field and, therefore, its very basis which is the gist of its very isness. For this reason, the field of isness can be conceived as dependent upon subject as upon Dasein absolved from Being and having thus turned into the basis for all isness (for all beings). The possibility of Dasein's turning into "mere" subject - the possibility of concealing Being and also losing the possibility of authentic communication - was granted by the omission of distinguishing between these two meanings. Only by understanding the transcendental subject as Dasein are we able, again, to unconceal Being and to enter authentic communicative relationships based on the authentic understanding of discourse.

To succeed where the Greeks allegedly failed, Heidegger draws also on the stock of medieval Christian philosophy - on the notion of God's intentionality with which the human 
soul shares an intimate connection (cf. Kisiel, 1993, p. 31; Mojsisch \& Summerell, 2011). For the medieval feeling, the pure "transcendental" givenness of things is not the most basic as there is still one deeper level to go to - that of God. By meeting the transcendence of God, Man is able grasp the dependence of his mind and its contents (the world) on God. By using this medieval notion of soul's primordial relation to God, Heidegger will get the modern "subject" to remember (to unconceal) its dependence on and interdependence with Being and the field of isness will reveal itself as a gift of Being to be treasured.

We can assert quite safely that both Being and Time and even the whole of Heidegger's thought revolves about this twofold possibility of revealing (concealing or un-concealing) ousia: hence, the destruction of upokeimenon and the Greek ontology, upon which the modern ("Cartesian") subject rests, goes hand in hand with a novel retrieval of ousia, or Being as un-concealed, empowered by Christian experience of transcendence and the ex nihilo. Also, importantly, just like the Christian notion of creation ex nihilo conceives human mind, which includes all creation, to be in constant relation to actus essendi (the act that gives it origin) - and thus the mind "follows" each ontologically created and sustained being in time and gives it unity (Aleksandravičius, 2009, p. 219), so Heideggerian thinking of Being and of beings as unconcealed in Dasein also avoids the infamous dualism of object and subject. Accordingly, the ontologically basic division of the world into separated subjects or atoms is also gone to yield room to communicative Dasein.

\section{Creativity as receptivity in ecstatic time}

We must also discuss another related meaning of passivity or receptivity which Heidegger retrieves from Aristotelian notion of pathos. ${ }^{2}$

In Being and Time Dasein as Being-in-the-world is described as ever already touched (angegangen) by innerwordly beings but only because Dasein is ever already intentional, ever intends - or reveals - the world (Heidegger, 2006, p. 137). This notion of Being-in-the-world refers back to the Aristotelian notion of the soul, or the mind of the soul (tês psuchès nous) (Heidegger, 1993, p. 326). Intentionality as revealing of the world or being involved in the world is characteristic, for Aristotle, of the nous and is described in terms of creation/work/ making: the ergon of the nous is dis-covery of the world. This ergon has two aspects. On the one hand, mind's being thrown into the world, his aprioric being in the world is its aspect of passivity: the being touched by the world and the innerwordly is the pathic aspect of the nous (Heidegger, 1993, p. 326). On the other hand, this meeting of things, this intentionality is the transcendental activity of the nous, or Dasein, its ergon: nous pathetikos is only possible because of nous poietikos, which uncovers the world (Heidegger, 1993, p. 326). This passivelyactive discovery of the world is Dasein or the field of presence, or energeia. Heidegger stresses that the unity of poèsis and pathēsis is essential for Greek thought and their understanding of life. Heidegger's reading of Aristotelian pathos is the predecessor of the existentials of Stimmung ("mood") and Befindlichkeit ("state-of-mind"). Pathos is not "emotion" but the condition of the possibility of any emotion or feeling, or, indeed, of any revelation of the

\footnotetext{
${ }^{2}$ For Heidegger, discourse, or communication, is inextricably united with pathos as it is well manisfested in Aristotle's Rhetoric (2015).
} 
world and of any discourse. Therefore, Heidegger, in Being and Time, describes Dasein as ever already having a mood (always being "bestimmt") and thus Befindlichkeit is a fundamental existential (2006, p. 134). Indeed, the primary uncovering of the world belong to "mere" feeling (construed ontologically as opposed to ontically) (Heidegger, 2006, p. 138).

The Aristotelian unity of pathessis and poiesis is, in Being and Time, conveyed in terms of throwness (Geworfenheit) as the passive aspect and understanding (Verstehen) as the active aspect: every understanding has its mood, every mood understands (Heidegger, 2006, p. 335).

Heidegger's notion of Being's temporality is based on the Greek understanding of Being in terms of kinessis. While kinessis is defined precisely by the unity of poessis and pathēsis; for this reason, Plato is able to conceive of all Being as "poetic" (see Steadman, 2014; Stasiulis, 2016b).

Hence, Heideggerian thought depends on the individualizing (Christian) experience of the creation out of nothing, based on which he is able to reinterpret the inherited concepts of Aristotle and to read the notion of ontological difference out of the Greek Dasein. He thus is able to avoid both the dualism of subject and object and the opposition between Greek "cyclical" thought (traditionally conceived as) oriented toward unity and the "individualistic" Christian linear time based on the creation of novelty out of nothing. Thus, he is able to help Greek and Christian revelations of godliness befriend and to root creativity in the newly discovered notion of piety as the condition of authentic communication.

We can see this reconciliation of ancient "circular" and "definite" thought with thought based on "novelty" in Heidegger's phenomenological reading of Aristotle notion of "eternity". The dualism of "definiteness" versus "novelty" is substituted with a phenomenological opposition between "authentic" and "inauthentic" - or, we could say, pious and impious - thought. The aei, aidion, according to Heidegger, first of all denotes the "now", the "presence" which is the gist of Greek thought. In the concept of aidion, aidion is opposed to ginomenon apeirakis. Heidegger stresses that it does not mean a difference between "eternity" and "temporality", "time" (1976, p. 268). In the latter non-Greek differentiation, "eternity" denotes a duration with has no limit, no beginning and end, while "time" denotes something limited. But for Greeks it is all the contrary: the limitless is precisely what is opposite to aidion. Heidegger explains that for the Greeks this limitless means something that sometimes is, sometimes is not. Thus, for the Greeks the limit - peras - does not denote either an external delimitation or a coming to a stop but rather it means something that defines in the sense of providing a basis (Halt) and a stand (Bestand) (Heidegger, 1976, p. 269), the reason why something begins and is present. While what is limitless is verfallen, it has fallen to the inauthentic (unecstatic) way of being (and to mere "ideal discourse"). In this sense of the forgetfulness of Being Heidegger (1980) defines our current way of being as limitless and, hence, subject to hubris (the pride of genius) (cf. the endnote to The Origin of the Work of Art (in German: Der Ursprung des Kunstwerkes, originally published in 1950).

\section{Conclusions}

Heideggerian thinking provides an original way of approaching the metaphysics or the ontology upon which our everyday and our key practical notions of communication rest. The oppositions between the whole and the individual, between the definite and the creative seem 
to lose meaning as Heidegger undermines both the modern notion of genius and, what is more, all Western metaphysics. Even more importantly, his thinking outlines an original notion of creativity which takes up and transforms the notion of novel creation from nothing by eventually substituting it with the notion of ecstatic creation as unconcealment. Herein we can have a clue of a new notion of piety which is yet completely formal and general but which is to inform future creativity and to become the root of communication.

I think there is also another key meaning to Heidegger's work. As it has been contributing to destroying our current conceptual and scientific and political thought and, simultaneously, has been uncovering ways to read the context of Greek and, hence, our own thought in new ontological light, it has given us the opportunity to reread ancient texts - especially those key texts of Plato's and Aristotle's - without our customary pre-conceptions about their sense. I suggest that we would not fail to acquire new insights into our condition if we attempted to read works of Plato and Aristotle not as exercises in conceptual thought but as exercises in unconcealment. For instance, Plato's (2000) Republic (in Greek: Politeia, originally published in $380 \mathrm{BC}$ ) read thus, could appear to be an entertaining utopia of the creative city and to provide an exemplary model of communication. This is the task to be taken up in the future.

\section{References}

Aleksandravičius, P. (2009). Tomo Akviniečio laiko samprata. Problemos, 76, 206-224.

Aristotle. (1984). Physics. In J. Barnes (Ed.), The complete works of Aristotle. The revised Oxford translation (pp. 2-161). Vol. 1. Series: Bollingen Series LXXI: 2. New Jersey: Princeton University Press.

Aristotle. (2015). Rhetoric. Fairhope, AL: Mockingbird Classics Publishing.

Choi, Y., \& Dattilo, J. (2017). Connections between media technology and leisure: insights from Aristotle and Heidegger. Annals of Leisure Research, 20(2), 152-168. https://doi.org/10.1080/11745398.2016.1184097

Černevičiūtè, J., \& Strazdas, R. (2014). Kūrybingumo sampratų raida: nuo genijaus ị kūrybines sistemas. Santalka: filosofija, komunikacija, 22(2), 113-125.

Heidegeris, M. (1980). Meno kūrinio prigimtis. Iš B. Kuzmickas (sud.), Grožio kontūrai: iš XX amžiaus užsienio estetikos (pp. 208-255). Vilnius: Mintis.

Heidegeris, M. (1992). Tapatybès tezè. Iš A. Šliogeris (sud.), Rinktiniai raštai (pp. 331-342). Vilnius: Mintis.

Heidegger, M. (1990). Gesamtausgabe. II. Abteilung: Vorlesungen. Bd. 33: Aristoteles, Metaphysik $\Theta$, 1-3. Vom Wesen und Wirklichkeit der Kraft. H. Hüni (Hrsg.). Frankfurt am Mein: Vittorio Klostermann.

Heidegger, M. (2005). Gesamtausgabe. II. Abteilung: Vorlesungen. Bd. 62: Phänomenologische Interpretationen ausgewählter Abhandlungen des Aristoteles zur Ontologie und Logik. Neumann, G. (Hrsg.). Frankfurt am Mein: Vittorio Klostermann.

Heidegger, M. (1993). Gesamtausgabe. II. Abteilung: Vorlesungen 1919-1944. Bd. 22: Die Grundbegriffe der antiken Philosophie. Blust, F.-K. (Hrsg.). Frankfurt am Mein: Vittorio Klostermann.

Heidegger, M. (2006). Sein und Zeit. Tübingen: Max Niemeyer Verlag.

Heidegger, M. (1976). Vom Wesen und Begriff der Фúఠıc. Aristoteles, Physik B, 1, in Herrmann, von F.-W. (Hrsg.). Gesamtausgabe. I. Abteilung: Veröffentlichte Schriften 1910-1976 (pp. 203-238). Bd. 9: Wegmarken. Frankfurt am Mein: Vittorio Klostermann. 
Kačerauskas, T. (2012). Creative economy and technologies: social, legal and communicative issues. Journal of Business Economics and Management, 13(1), 71-80. https://doi.org/10.3846/16111699.2011.620151

Kačerauskas, T. (2014). Kūrybos visuomenès terminai ir sampratos. Logos: religijos, filosofijos, komparatyvistikos ir meno Žurnalas, 78, 6-18.

Kisiel, Th. (1993). The genesis of Heidegger's being and time. London: University of California Press, Ltd.

Mojsisch, B., \& Summerell, O. F. (2011). Meister Eckhart. Stanford Encyclopedia of Philosophy. Retrieved from https://plato.stanford.edu/entries/meister-eckhart/

Ou Yang, Sh. (2016). Returning to the philosophical roots of sociomateriality: how M. Heidegger and M. McLuhan questioned information communication technology. ACM SIGMIS Database: The DATABASE for Advances in Information Systems, 47(4), 93-105. https://doi.org/10.1145/3025099.3025109

Parastoo Saeidi, S., Haji Othman, M. Sh., Štreimikienè, D., Saeidi, S. P., Mardani, A., \& Stasiulis, N. (2018). The utilitarian aspect of the philosophy of ecology: the case of corporate social responsibility. Filosofija. Sociologija, 29(1), 39-51. https://doi.org/10.6001/fil-soc.v29i1.3630

Plato. (1993). Sophist. Indianapolis: Hackett Publishing Company, Inc.

Platonas. (2000). Valstybè. Vilnius: Pradai.

Rimkus, E. (2018). Vartojimo revoliucijos ir kontrrevoliucijos: filosofijos, sociologijos ir komunikacijos tyrimai. Filosofija. Sociologija, 29(3), 211-219.

Stasiulis, N. (2018a). Heidegeriškoji naudos ontologija. Logos: religijos, filosofijos, komparatyvistikos ir meno Žurnalas, 94, 6-12.

Stasiulis, N. (2018b). Vartojimo ontologija. Retrieved from https://www.youtube.com/watch?v= 2yN85lVATYU

Stasiulis, N. (2016a). On the conception of the creative in natural science and philosophical reflections thereof. Creativity Studies, 9(1), 42-52. https://doi.org/10.3846/23450479.2015.1114041

Stasiulis, N. (2016b). On the unity of theory and practice in Heidegger's thought. Filosofija. Sociologija, 27(3), 249-256.

Steadman, G. (2014). Plato's symposium: Greek text with facing vocabulary and commentary. Oxford: Oxford University Press.

Sturgess, J. N. (2016). Drawing from Heidegger: Dasein and the question of communication. Empedocles: European Journal for the Philosophy of Communication, 7(1), 23-37.

https://doi.org/10.1386/ejpc.7.1.23_1

Vlăduțescu, Ș. (2014). Communication of silence at Martin Heidegger: sygetics - logics of thinking silence. International Letters of Social and Humanistic Sciences, 17, 49-54.

https://doi.org/10.18052/www.scipress.com/ILSHS.17.49

\title{
KOMUNIKACINIS KŪRYBIŠKUMAS: NUO İPRASTINĖS METAFIZIKOS PRIE ORIGINALIOS ONTOLOGIJOS
}

\author{
Nerijus Stasiulis \\ Santrauka
}

Straipsnyje tiriamas kūrybos komunikacijos visuomenèje ir kūrybinio miesto metafizinis pamatas, taip pat siekiama atrasti praktinių problemų, su kuriomis šiandien susiduriame kasdienybeje ir ekonomikoje, metafizinius pagrindus. Susitelkiama i genijaus metafiziką ir ankstesnę krikščioniškąją kūrimo iš nieko metafiziką, taip pat ir i individualios valios svarbą kaip genialumo sampratos pirmtakus. Vakarų racionalizmas, kurio viena iš apraiškų yra apibrěžtos mokslų ribos ir iracionalizmas, 
o jo apraiška yra genijaus metafizika, vis dar nustato mūsų šiandienės minties bei polemikos rèmus autorių ir patentų teisių, mokslų ir menų komunikacijos (t. y. bendradarbiavimo) klausimais. Ištyrus praktinès problematikos metafizinị kontekstą, pateikiama haidegeriškoji Vakarų metafizikos pertvarka, siekiant suformuoti originalią ontologiją, kurios tikslas - formuoti praktiką ateityje. Parodoma, kad pati ekstatinio laiko samprata yra itin reikšminga originaliam kūrybiškumui.

Reikšminiai žodžiai: autorių teisès, kūrybiškumas, genijus, Heideggeris, darpdalykinè komunikacija, ontologija, patentų teisè. 